\title{
PROSES PENGEMBANGAN KURIKULUM
}

\author{
Karima Nabila Fajri \\ Universitas Islam Negeri Sunan Kalijaga Yogyakarta \\ karimanabila4@gmail.com
}

\begin{abstract}
The curriculum is one component and guideline that facilitates the implementation of education in achieving its objectives. The curriculum becomes an important component in education, because it regulates all educational processes from planning to evaluation. The curriculum development process is a step to develop a curriculum, it can also be interpreted as steps to produce a curriculum or perfect an existing curriculum. In curriculum development there are supporting factors and inbibitors that influence. This study discusses the curriculum development process, the stages of curriculum development, and the supporting factors of inbibiting funds in the curriculum development process. The method used in this draft article is library research, by examining some literature on curriculum development. How can you know the curriculum development process that is being carried out to develop the curriculum.
\end{abstract}

Keywords: Process, Development, Curriculum

\begin{abstract}
Abstrak : Penelitian Kurikulum merupakan salah satu komponen dan pedoman yang memudahkan pelaksanaan pendidikan mencapai tujuannya. Kurikulum menjadi komponen penting dalam pendidikan, karena mengatur semua proses pendidikan mulai dari perencanaan hingga evaluasi. Proses pengembangan kurikulum merupakan langkah-langkah untuk mengembangkan suatu kurikulum, dapat juga diartikan sebagai langkah-langkah untuk menghasilkan kurikulum atau menyempurnakan kurikulum yang telah ada. Dalam pengembangan kurikulum terdapat faktor pendukung dan penghambat yang mempengaruhi. Kajian ini membahas mengenai proses pengembangan kurikulum, tahapan-tahapan pengembangan kurikulum, dan faktor pendukung dana penghambat dalam proses pengembangan kurikulum. Metode yang digunakan dalam penyusunan artikel ini adalah library research, dengan menelaah beberapa literatur mengenai pengembangan kurikulum. Hasilnya dapat mengetahui proses pengembangan kurikulum sehingga mengetahui langkah yang dilakukan untuk mengembangkan kurikulum.
\end{abstract}

Kata Kunci : Proses, Pengembangan, Kurikulum

Islamika : Jurnal Keislaman dan Ilmu Pendidikan

Volume 1, Nomor 2, Juli 2019; 35-48

https:// ejournal.stitpn.ac.id/index.php/islamika 


\section{PENDAHULUAN}

Zaman mengalami perkembangan dan perubahan di berbagai bidang. Perkembangan dan perubahan tersebut dapat mempengaruhi perubahan sistem pendidikan. Pada zaman sekarang, pendidikan menjadi hal penting dalam kehidupan bermasyarakat, karena dengan pendidikan dapat merubah kualitas hidup seseorang. Hal dapat dibuktikan ketika semakin tinggi pendidikan maka wawasan ilmu dan pengalaman yang dimiliki juga bertambah sehingga memudahkan seseorang dalam menyelesaikan masalah dalam kehidupan. Salah satu pondasi pendidikan adalah kurikulum sehingga apabila terjadi perkembangan zaman dari berbagai bidang dapat mempengaruhi sistem pendidikan, maka terjadi pula perkembangan kurikulum. Problem-problem yang muncul pada masyarakat juga mendorong perubahan sistem pendidikan. Kurikulum hadir untuk menyelesaikan problem dan menjawab tuntutan di masyarakat. Kurikulum disusun untuk memudahkan berjalannya proses pendidikan yang ada.

Dalam kurikulum terdapat proses pengembangan yang secara umum terdiri dari perencanaan, implementasi dan evaluasi. Proses pengembangan ini bertujuan untuk menciptakan kurikulum yang efektif. Terdapat beberapa tokoh yang merumuskan tahapan dalam pengembangan kurikulum. Akan tetapi pada proses pengembangan kurikulum dipengaruhi oleh beberapa faktor yang mendukung, ada pula hambatan-hambatan dalam pengembangan kurikulum.

\section{METODE}

Dalam kajian ini, penulis menggunakan metode library research yaitu dalam penulisan artikel penulis menggunakan buku-buku sebagai sumber datanya. ${ }^{1}$ Library research yang biasa disebut penelitian pustaka dilakukan dengan menelaah sumber yang sifatnya tertulis. Sifat penelitian ini adalah deskriptif-analitik, dibahas dengan jelas, runtun, dan terarah. Subyek penelitian dalam artikel ini dari data sekunder. Sumber sekunder, yaitu data yang diperoleh bukan dari buku induk tetapi dari buku buku tersebut memuat suatu data-data yang mendukung. ${ }^{2}$ Biasanya buku-buku ini hasil telaah dari buku induk. Sumber sekunder yang digunakan dalam artikel ini

\footnotetext{
${ }^{1}$ Sutrisno, Hadi, Metodologi Research, Jilid I, (Yogyakarta: Andi Offset, 2004) hal. 9

2 Tatang M. Amirin, Menyusun Rencana Penelitian, (Jakarta: Rajawali Press, 2000), hal. 132.
} 
berasal dari buku- buku yang membahas hal-hal yang berhubungan dengan proses pengembangan kurikulum.

\section{PEMBAHASAN}

\section{Proses Pengembangan Kurikulum}

Kurikulum merupakan salah satu komponen penting dalam pendidikan, kurikulum diartikan sebagai suatu program yang disediakan untuk siswa. Sebagaimana yang dijelaskan oleh Oemar Hamalik dalam buku manajemen pengembangaan kurikulum, kurikulum merupakan suatu program yang disediakan untuk siswa. Program pendidikan dalam bentuk kegiatan belajar, tujuannya untuk meningkatkan perkembangan dan pertumbuhan siswa yang disesuaikan dengan tujuan pendidikan. Pengembangan kurikulum merupakan suatu proses yang menyeluruh sebagai bentuk kebijakan nasional dalam pendidikan yang disesuaikan dengan visi, misi dan strategi yang dimiliki dari pendidikan nasional. Proses pengembangan kurikulum mulai dari perencanaan, pelaksanaan, monitoring dan evaluasi. ${ }^{3}$

Pengembangan kurikulum diartikan sebagai suatu proses, maka dalam pelaksanaannya terdiri beberapa langkah yang harus dilakukan sebagaimana yang digambarkan oleh Hasan (2002) yang dikutip oleh Muhaimin dalam chart berikut ini,

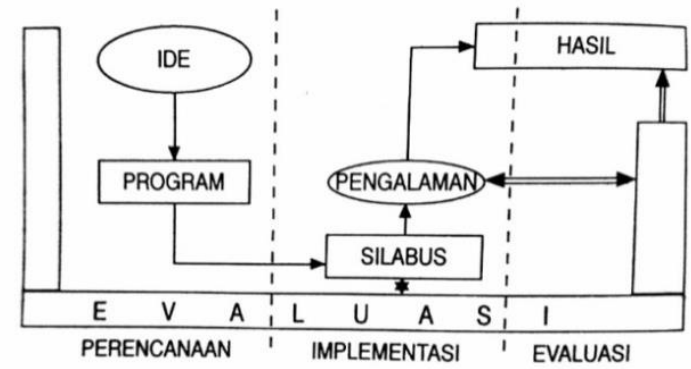

Chart di atas menggambarkan proses pengembangan kurikulum mulai dari perencanaan kurikulum hingga evaluasi. Dalam perencaan kurikulum dimulai dengan merumuskan ide yang akan dikembangkan menjadi program. Ide dalam perencaan kurikulum berasal dari: 2012) hal.22

${ }^{3}$ Oemar Hamalik, Manajemen Pengembangan Kurikulum, ( Bandung: PT remaja Rosdakarya,

${ }^{4}$ Muhaimin, Pengembangan Kurikulum Pendidikan Agama Islam di Sekolah, Madrasah, dan Perguruan Tinggi, (Jakarta: PT RajaGrafindo Persada, 2012) hal. 12 
1. Visi yang dicanangkan

2. Kebutuhan stakeholders dan kebutuhan untuk studi jenjang berikutnya

3. Hasil evaluasi kurikulum yang telah digunakan dan tuntutan perkembangan ipteks dan zaman

4. Pandangan berbagai pakar keilmuan

5. perkembangan era globalisasi, di mana seseorang dituntut untuk memiliki etos belajar sepanjang hayat, memperhatikan bidang sosial, ekonomi. Politik, budaya dan teknologi. ${ }^{5}$

Dari ide di atas kemudian dikembangkan rancangan program dalam bentuk dokumen seperti format silabus. Rancangan tersebut dikembangkan lagi dalam bentuk rencana pembelajaran yang akan dilaksanakan seperti RPP atau SAP. Rencana tersebut berisi tentang langkah pembelajaran untuk siswa. Setelah rencana tersebut diterapkan kemudian dievaluasi sehingga dapat diketahui tingkat efektivitasnya. Dari hasil evaluasi ini akan diperoleh bekal untuk menyempurnakan kurikulum berikutnya. ${ }^{6}$

Dari penjelasan di atas proses pengembangan kurikulum secara umum terdiri dari perencanaan, implementasi, serta evaluasi. Selain proses kurikulum secara umum diatas, ada empat tahap pengembangan kurikulum dilihat dari tingkatannya antara lain:

1. Pengembangan kurikulum pada tingkat nasional.

Pengembangan kurikulum pada tingkat ini membahas pendidikan pada tingkat nasional yang terdiri dari pendidikan formal, informal, dan non formal. Dari tingkatannya dapat dilihat secara vertikal dan horizontal. Secara vertikal, pengembangan kurikulum dilakukan berdasarkan tingkatan pendidikan dari yang terendah sampai ke tinggi. Sedangkan Secara horizontal, pengembangan kurikulum berdasarkan pendidikan yang sederajat, seperti contoh SD, MI, dan program paket $\mathrm{A}^{7}$

${ }^{5}$ Ibid., hal. 12-13

${ }^{6}$ Ibid., hal.13

7 Zainal Arifin, Konsep dan Model Pengembangan Kurikulum, ( Bandung: PT Remaja Rosdakarya, 2013), hal. 41 
2. Pengembangan kurikulum pada tingkat institusi

Pengembangan kurikulum tingkat ini memiliki beberapa kegiatan yangb harus dilaksanakan antara lain, merumuskan tujuan yang akan dicapai sekolah, menyusun SKL (standar kompetensi lulusan), dan penetapan isi kurikulum secara keseluruhan. Standar kompetensi lulusan berupa rumusan kompetensi pengetahuan, keterampilan, dan sikap yang harus dicapai oleh siswa setelah mengikuti pembelajaran pada lembaga pendidikan. SKL tersebut dirumuskan sesuai dengan jenis dan tingkatannya.

Standar kompetensi lulusan menunjukkan harapan masyarakat, seperti orangtua, penjabat pemerintah dan swasta tentang dunia pendidikan, dunia usaha, dan lain-lain, serta merupakan harapan bagi pendidikan jenjang tinggi atau dunia kerja. ${ }^{8}$

3. Pengembangan kurikulum pada tingkat mata pelajaran

Silabus merupakan bentuk pengembangan kurikulum pada tingkat mata pelajaran. Silabus yang terdiri dari kompetensi inti, kompetensi dasar, materi pokok, kegiatan pembelajaran, indikator pencapaian, bentuk penilaian dan alokasi waktu disusun pada setiap semester. ${ }^{9}$

4. Pengembangan kurikulum pada tingkat pembelajaran di kelas.

Pada tingkat pembelajaran dikelas pengembangan kurikulum dilakukan dalam bentuk susunan RPP ( Rencana Pelaksanaan Pendidikan) yang dirancang oleh masing-masing guru. Perencanaan tersebut juga meliputi sumber belajar yang akan digunakan. ${ }^{10}$

Penjelasan di atas merupakan bentuk pengembangan kurikulum pada tiap-tiap tingkatannya. Masing-masing tingkatan memiliki tugas masing-masing dalam proses pengembangan kurikulum, akan tetapi tetap disesuaikan dengan tujuan pendidikan nasional. Sedangkan menurut Hamalik proses pengembangan kurikulum yang digunakan di Indonesia dimulai dengan melihat kebutuhan yang ada. Dari studi kebutuhan serta kelayakan kemudian menyusun rencana kurikulum, rencana awal

\footnotetext{
${ }^{8}$ Ibid., hal.41

${ }^{9}$ Ibid., hal. 42

${ }^{10}$ Ibid., hal. 43
} 
dikembangkan menjadi rencana yang akan diterapkan dalam pelaksanaan kurikulum. Rencana tersebut di uji coba terlebih dahulu di lapangan sebelum kurikulum dilaksanakan secara menyeluruh. Setelah dilaksanakan secara menyeluruh kemudian dilakukan penilaian untuk melihat tingkat keberhasilan kurikulum. Hasil penilaian dapat digunakan untuk perbaikan kurikulum yang telah ada. ${ }^{11}$

\section{Tahapan Pengembangan Kurikulum Menurut Para Ahli}

Ada beberapa para Ahli yang merumuskan tahapan-tahapan pengembangan kurikulum, sebagai berikut:

1. Model administratif

Model administratif adalah model tertua yang pernah digunakan. Pengembangan dengan model adminisratif dilakukan oleh administrator pendidikan yang membentuk suatu tim pengarahan pengembangan kurikulum.

Model administratif sering pula disebut sebagai model garis. Sehingga pengembangan kurikulum diarahkan dari penjabat pendidikan yang berada di atas. Kemudian membentuk tim pengarahan yang terdiri dari pengawas, kepala sekolah dan pengajar. Tim pengarahan memiliki ugas untuk merencanakan, memberikan pengarahan, merumuskan falsafah dan tujuan umum pendidikan. ${ }^{12}$

Selanjutnya, tim pengarahan membentuk kelompok kerja untuk menyusun tujuan pendidikan, rencana pengajaran, dan kegiatan pembelajaran. Hasil kerja kelompok tersebut direvisi oleh tim pengarah dan dilakukan uji coba. Kegiatan uji coba bertujuan untuk melihat tingkat efektifitas dan kelayakannya. Tim pengarah menelaah dan mengevaluasi uji coba rancangan kurikulum kemudian memutuskan pelaksanaannya. Pengembangan kurikulum model administratif tersebut dapat dilaksanakan pada negara yang dengan sistem karena model ini dari pusat ke bawah. Kekurangan model ini

\footnotetext{
${ }^{11}$ Oemar Hamalik, Manajemen Pengembangan Kurikulum... hal.142-143

12 Sholeh Hidayat, Pengembangan Kurikulum Baru ( Bandung: PT Rosdakarya Offset, 2013) hal.
} 
kurikulum biasanya bersifat seragam secara nasional sehingga tidak disesuaikan dengan kebutuhan tiap-tiap daerah. ${ }^{13}$

Dalam pelaksanaan kurikulum tersebut, dilakukan kegiatan monitoring, pengamatan, pengawasan, dan bimbingan yang kemudian dilakukan pula evaluasi yang hasilnya di gunakan untuk umpan balik bagi instansi pendidikan tingkat pusat, daerah, dan sekolah. Dalam pelaksanaannya perlu adanya pengawasan. Kekurangan model ini dapat dijadikan pertimbangan dalam memilih model pengembangan kurikulm karena tuntutan masing-masing daerah berbeda-beda.

2. Menurut Arich Lewy

Menurut Arich Lewy (1977) proses pengembangan kurikulum dilaksanakan melalui beberapa tahapan sebagaimana yang dikutip dalam buku dasar-dasar pengembangan kurikulum karya Burhan Nurgiyanto terdiri dari penentuan tujuan umum, perencanaan, uji coba dan revisi, uji lapangan, pelaksanaan kurikulum dan pengawasan mutu kurikulum.

Penjelasan dari enam tahap pengembangan menurut Arich Lewy, tahap pertama yang dilakukan dalam proses pengembangan kurikulum adalah merumuskan tujuan kurikulum secara umum. Tujuan kurikulum tersebut meliputi nilai dan kompetensi yang harus dimiliki oleh peserta didik setelah mengikuti pelaksanaan kurikulum. Dalam merumuskan tujuan ini, para pengembang kurikulum bekerja sama dengan para ahli disiplin ilmu termasuk psikolog, sosiolog, antropolog, dan pakar-pakar ilmu lainnya yang relevan. Pakar-pakar ini dianggap mampu memberikan kontribusi pemikirannya untuk merumuskan tujuan umum kurikulum. ${ }^{14}$

Berdasarkan tahaapan pertama, selanjutnya pengembang kurikulum menyusun perencanaan kurikulum, mulai dari perencanaan umum (silabus) sampai dengan perencanaan khusus (RPP) dalam berbagai kegiatan (intrakulikuler, ekstrakulikuler maupun kokulikuler) sesuai dengan organisasi kurikulum yang diinginkan. Perencanaan meliputi bahan/materi

${ }_{13}$ Burhan Nurgiyanto, Dasar-dasar Pengembangan Kurikulum, (Yogyakarta: BPFEE, 1988), hal. 169.

${ }^{14}$ Ibid., hal.43 
pembelajaran, strategi penyampaian, sistem penilaian, sarana prasarana, biaya serta cara-cara penyampaian kepada guru-guru agar mereka dapat menggunakannya. Perencanaan yang sudah disusun kemudian di uji coba. Uji coba bertujuan untuk menguji perancaan kurikulum yang telah disusun sesuai dengan situasi dan kondisi objektif di lapangan. Selain itu uji coba juga dilaksanakan untuk mengetahui kelemahan dari perencaan sehingga dapat diperbaiki. Dalam uji coba ini, pengembang kurikulum melakukan observasi secara langsung di kelas dan meminta pendapat peserta didik mengenai kegiatan pembelajaran dengan kurikulum baru yang telah diikuti. Begitu juga pendapat dari para pakar pendidikan, psikologi, bidang studi, dan lain-lain termasuk kepala sekolah,orang tua, guru. ${ }^{15}$

Hasil uji coba terbatas adalah memperoleh kurikulum yang lebih baik. Berdasarkan kurikulum ini kemudian dilakukan kembali uji lapangan yang lebih luas, yang hampir mirip dengan situasi sebenarnya. Tujuannya untuk menganalisis kondisi pelaksanaan kurikulum agar diperoleh hasil yang lebih memadai. Setelah dilakukan uji lapangan, kemudian dilaksanakan pelatihan untuk kepala sekolah dan guru secara bertahap. Selanjutnya kurikulum dilaksanakan seluruh sekolah di berbagai wilayah dalam suatu negara secara uniform. Kurikulum memiliki sifat dinamis, yaitu mengikuti perubahan dan perkembangan zaman. Apabila kurikulum memiliki kekurangan dan tidak dapat mengikuti perkembangan zaman, maka perlu dilakukan pembaharuan kurikulum. ${ }^{16}$

3. Model Rogers

Terdapat tahap pengembangan kurikulum dengan model Rogers. tahap pertama yang dilakukan yaitu memilih target yang akan ikut serta dalam kelompok intensif dari sistem pendidikan, selanjutnya guru berpartisipasi dalam pengalaman guru. Pengalaman yang ada dikembangkan pada masingmasing kelas. Dibutuhkan pula partisipasi orang tua dalam kegiatan

\footnotetext{
15 Ibid.,hal..44

${ }^{16}$ Ibid., hal.44
} 
kelompok. ${ }^{17} \quad$ Akan tetapi dalam tahapan model ini tidak semua orang tua ikut serta dalam menyusun kurikulum. Orang tua memiliki peran lebih besar pada saat pelaksanaan kurikulum. Karena dalam proses belajar tidak hanya berlangsung di sekolah tetapi juga di rumah, sehingga orang tua ikut mendampingi dan mengawasi kegiatan belajar siswa di rumah. Orang tua juga dapat turut berpartisipasi dalam kegiatan di sekolah melalui berbagai kegiatan seperti diskusi, pertemuan dengan guru dan pelaporan hasil belajar. Dari kegiatan tersebut dapat menjadi umpan balik untuk menyempurnakan kurikulum. ${ }^{18}$ Proses pengembangan kurikulum dengan model rogers lebih memperhatikan subyek yang berpegaruh dalam pelakasanaan kurikulum.

4. Menurut Tyler

Menurut Tyler, tahapan pengembangan kurikulum terdiri dari empat tahapan mulai dari menentukan tujuan hingga penilaian. Pertama, menentukan tujuan pengembangan kurikulum, tahapan yang harus dilakukan pertama yaitu menentukan tujuan dari pengembangan kurikulum. Sehingga dapat diketahui arah dan sasaran pencapaian pendidikan. Kedua, menentukan pengalaman belajar siswa. Setelah menentukan tujuan kemudian pada tahap selanjutnya dilakukan penentuan pengalaman belajar (learning experiences). Pengalaman belajar merupakan kegiatan interaksi siswa dengan lingkungan. Pengalaman belajar siswa dapat ditemui dalam proses pembelajaran. Terdapat beberapa prinsip dalam menentukan pengalaman belajar yaitu pengalaman disesuaikan dengan tujuan yang hendak dicapai, setiap pengalaman harus memuaskan siswa, siswa terlibat dalam perencanaan pengalaman belajar, dan dalam pengalaman belajar siswa memiliki tujuan yang berbeda-beda.

Ketiga, pengorganisasian pengalaman belajar. Pengorganisasian ini dibagi menjadi 2 jenis yaitu secara vertikal dan horizontal. Untuk pengorganisasian secara vertikal menghubungkan pengalaman belajar suatu kajian ilmu yang sama pada tingkatan yang berbeda. Sedangkan secara horizontal menghubungkan pengalaman belajar beberapa bidang pada tingkat

${ }^{17}$ Nana Syaodih Sukmadinata, Pengembangan Kurikulum Teori dan Praktek, ( Badung: PT Remaja Rosdakarya, 2012) hal.167

${ }^{18}$ Ibid., hal 168 
yang sama. Keempat, penilaian tujuan belajar sebagai komponen yang dijadikan perhatian utama ${ }^{19}$

5. Menurut Beauchamp

Ada lima tahapan dalam mengembangkan suatu kurikulum yang pertama menetapkan lingkup wilayah yang akan di cakup oleh kurikulum tersebut (sekolah, kecamatan, kabupaten, propinsi, Negara). Tahapan lingkup wilayah ini ditentukan oleh pihak yang memiliki wewenang untuk mengambil kebijakan dalam pengembangan kurikulum. Setelah menetapkan lingkup wilayah kemudian menetapkan personalia yaitu pihak yang ikut dalam proses pengembangan kurikulum. Menurut Beauchamp pihak tersebut antara lain, para ahli pendidikan ataupun ahli kurikulum yang berada di tingkat pusat, perguruan tinggi dan sekolah. Selain itu juga para profesional dalam sistem pendidikan serta tokoh-tokoh masyarakat yang berpengaruh dalam pendidikan. $^{20}$

Dalam model ini melibatkan para ahli dan tokoh pendidikan yang berpengaruh pada pengembangan kurikulum baik secara langsung maupun tidak. Penetapan ini disesuaikan dengan tingkat dan luas wilayah. Sebagaimana untuk tingkat provinsi dan nasional tidak begitu melibatkan guru. Sebaliknya untuk tingkat dibawahnya seperti kabupaten, kecamatan, dan sekolah keterlibatan guru lebih besar dalam pengembangan kurikulum. Organisasi dan prosedur pengembangan kurikulum. Langkah ini berkenaan dengan prosedur yang harus ditempuh dalam merumuskan tujuan umum dan tujuan khusus, memilih isi dan pengalaman belajar serta kegiatan evaluasi, dan dalam menentukan keseluruhan desain kurikulum. Selanjutnya mengimplementasikan kurikulum dan mengevaluasi. ${ }^{21}$

19 Abdullah Idi , "Pengembangan Kurikuum: Teori dan Praktik", ( Yogyakarta: AR- Ruzz Media,2016) hal. 177-179

${ }^{20}$ Nana Syaodih Sukmadinata, Pengembangan Kurikulum Teori dan Praktek,... hal. 163

${ }^{21}$ Ibid., 164 
6. Menurut Taba

Proses pengembangan kurikulum menurut taba dapat dilakukan dengan lima langkah. Dimulai dengan Mengadakan unit-unit eksperimen bersama guru-guru Didalam unit ini diadakan studi yang seksama tetang hubungan antara teori dan praktik. Perencanaan didasarkan atas teori yang kuat, dan pelaksanaan eksperimen didalam kelas menghasilkan data-data yang untuk menguji landasan teori yang digunakan. Ada 8 langkah dalam kegiatan unit eksperimen menurut Taba yaitu ,Mendiagnosis kebutuhan, merumuskan tujuan-tujuan khusus, memilih isi, mengorganisasi isi, memilih pengalaman belajar, mengorganisasi pengalaman belajar, mengevaluasi, melihat sekuens dan keseimbangan ${ }^{22}$

Selanjutnya menguji unit eksperimen, kegiatan ini dilaksanakan tidak hanya pada kelas ekperimen tetapi di uji juga pada kelas atau tempat lain sehingga dapat diketahui tingkat validitas dan juga dapat memperoleh data untuk penyempurnaan. Data yang diperoleh dari tahapan pengujian kemudian digunakan untuk perbaikan dan penyempurnaan. Selain melakukan revisi atau perbaikan juga diadakan konsolidasi, pada kegiatan ini dilakukan penarikan kesimpulan mengenai hal yang bersifat umum, karena unit eksperimen yang telah digunakan belum tentu valid untuk sekolah yang lain. ${ }^{23}$

Setelah melakukan kegiatan revisi dan konsolidasi, kemudian mengembangkan keseluruhan kerangka kurikulum. Pada tahapan ini dilaksanakan pengkajian oleh ahli kurikulum, tujuannya untuk mengetahui konsep dan landasan yang digunakan seusia atau tidak. Kemudian kurikulum baru diterapkan pada daerah yang lebih luas tidak hanya sekolah yang digunakan untuk eksperimen. Sehingga dengan langkah ini dapat diketahui maslah yang dihadapi, baik yang berkaitan dengan pendidik, fasilitas hingga pembiayaan. ${ }^{24}$

\footnotetext{
${ }^{22}$ Ibid., hal 166

${ }^{23}$ Ibid., hal 167

${ }^{24}$ Ibid,.hal. 167
} 


\section{Faktor yang Mempengaruhi Proses Pengembangan Kurikulum}

Dalam pengembangan kurikulum ada beberapa faktor yang mempengaruhi antara lain:

1. Perguruan tinggi

Kurikulum minimal mendapatkan 2 pengaruh dari perguruan tinggi yaitu dari segi pengembangan IPTEK yang dikembangkan perguruan tinggi dan dari segi pengembagan ilmu pendidikan dan keguruan serta penyiapan pendidik yang ada diperguruan tinggi. Pengetahuan dan teknologi memberikan sumbanga terhadap isi kurikulum dan proses pembelajaran.Pengetahuan dna teknologi banyak memberikan sumbangan bagi isi kurikulum serta proses pembelajaran. Pengetahuan yang berkembang di perguruan tinggi juga mempengaruhi isi materi ajar yang ada di kurikulum. perkembangan teknologi juga mendukung pengembangan kurikulum pada komponen alat dan media pendidikan. ${ }^{25}$

2. Masyarakat

Sekolah merupakan bagian dari masyarakat dan mempersiapjkan anak untuk kehidupan di masyarakat. Sebagai bagian dari mayarakat, sehingga pendidikan di sekolah dipengaruhi oleh lingkungan sekitar. Isi kurikulum yang ada seyogyanya dapat menjawab tuntutan dan kebutuhan yang ada di lingkungan masyarakat. ${ }^{26}$

3. Sistem nilai

Dalam lingkungan masyarakat terdapat sistem nilai, baik moral, agama, sosial, budaya, dan nilai politis. Seperti yang dijelaskan diatas sekolah sebagai bagian dari masyarakat dan salah satu lembaga mayarakat memiliki tanggung jawab untuk memelihara sistem nilai yang telah ada.. Sistem nilai yang akan dipelihara terintegrasikan dalam kurikulum. Masalah yang dihadapi dalam pemeliharaan sistem nilai adalah masyarakat bersifat heterogen dan multifaset, sehingga masing-masing kelompol etnis, vokasiomal, intelek, sosial, spiritual, dan sebagainya memiliki nilai yang berbeda. ${ }^{27}$

\footnotetext{
${ }^{25}$ Ibid., hal 158

${ }^{26}$ Ibid., hal 158

${ }^{27}$ Ibid, hal. 159
} 
Selain faktor-faktor diatas ada pula hambatan-hambatan pengemabngan kurikulum, hambatan yang pertama terletak pada pendidik. Pendidik atau guru yang menjadi pelaksana kurikulum kurang berpartisipasi dalam pengembangan kurikulum. Hal tersebut dikarenakan beberapa hal yaitu, kurang waktu, kekurangan sesuaian pendapat, baik antara sesama guru maupun dengan kepala sekolah dan administrator. Dan juga dikarenakan kemampuan dan tingkat pengetahuan guru. Hambatan yang lain datang dari masyarakat.

\section{KESIMPULAN}

Pengembangan kurikulum sebagai proses menyeluruh yang berkaitan dengan kebijakan nasional di bidang pendidikan, sesuai dengan visi, misi, dan strategi pembangunan pendidikan nasional. Ada empat tahap dalam pengembangan kurikulum menurut tingkatannya antara lain, Pengembangan kurikulum pada tingkat makro (Nasional), tingkat institusi ( sekolah), tingkat mata pelajaran (bidang studi), dan pada tingkat pembelajaran di kelas. proses pengembangan kurikulum secara umum terdiri dari perencanaan, implementasi, serta evaluasi. Ada beberapa tahapan pengembangan kurikulum menurut para ahli antara lain model administratif, Arich lewy, Rogers, Tyler, Beauchamp, dan Taba. Model pengembangan dapat dijadikan pedoman untuk menyusun proses pengembangan kurikulum. Dalam pengembangan kurikulum ada beberapa faktor yang mempengaruhi antara lain: faktor perguruan tinggi, masyarakat, dan sistem nilai

Selain faktor-faktor di atas ada pula hambatan-hambatan pengembangan kurikulum, hambatan yang pertama terletak pada guru. Guru sebagi subyek pelaksana kurikulum kurang berpartisipasi dalam pengembangan kurikulum. Hal ini dipengaruhi oleh beberapa hal yaitu, kurang waktu. kekurangan sesuaian pendapat, baik antara sesama guru maupun dengan kepala sekolah dan administrator. Dan faktor penghambat yang lain datang dari masyarakat. 


\section{DAFTAR PUSTAKA}

Arifin, Zainal , Konsep dan Model Pengembangan Kurikulum, Bandung: PT Remaja Rosdakarya, 2013

Hidayat, Sholeh, Pengembangan Kurikulum Baru Bandung: PT Rosdakarya Offset, 2013

Idi, Abdullah, Pengembangan Kurikuum: Teori dan Praktik, Yogyakarta: AR- Ruzz Media,2016

Oemar Hamalik, Manajemen Pengembangan Kurikulum, Bandung: PT remaja Rosdakarya, 2012

Nurgiyanto, Burhan, Dasar-dasar Pengembangan Kurikulum, Yogyakarta: BPFEE, 1988

Muhaimin, Pengembangan Kurikulum Pendidikan Agama Islam di Sekolah, Madrasah, dan Perguruan Tinggi, Jakarta: PT RajaGrafindo Persada, 2012

Syaodih,Nana Sukmadinata, Pengembangan Kurikulum Teori dan Praktek, Bandung: PT Remaja Rosdakarya, 2012 